\title{
Pengaruh Project Based Learning Terhadap Perilaku Prososial Anak Usia Dini
}

\author{
Santi Dianita ${ }^{1}$, Triyono ${ }^{2}$, Imron Arifin ${ }^{3}$ \\ ${ }^{1}$ Pendidikan Anak Usia Dini-Universitas Negeri Malang \\ ${ }^{2}$ Bimbingan dan Konseling-Universitas Negeri Malang \\ ${ }^{3}$ Administrasi Pendidikan-Universitas Negeri Malang
}

\begin{tabular}{l}
\hline \hline INFO ARTIKEL \\
\hline Riwayat Artikel: \\
Diterima: $01-04-2020$ \\
Disetujui: $18-09-2020$ \\
\hline
\end{tabular}

\section{Kata kunci:}

project based learning; prosocial behavior; early childhood; project based learning, perilaku prososial; anak usia dini

\author{
Alamat Korespondensi: \\ Santi Dianita \\ Pendidikan Anak Usia Dini \\ Universitas Negeri Malang \\ Jalan Semarang 5 Malang \\ E-mail: santidianita84@gmail.com
}

\begin{abstract}
ABSTRAK
Abstract: Early childhood needs to have prosocial behavior to socialize. Conventional learning causes low prosocial behavior. The purpose of this study was to determine the effect of project based learning on prosocial behavior of young children. This study uses a single subject research experimental design with three Group B kindergarten children as research subjects. Data collection using a rating scale prosocial behavior, showed an increase in prosocial behavior in all three subjects. The results of this study indicate that project based learning influences prosocial behavior of young children.

Abstrak: Anak usia dini perlu memiliki perilaku prososial untuk bersosialisasi. Pembelajaran konvensional menyebabkan rendahnya perilaku prososial. Tujuan penelitian untuk mengetahui pengaruh project based learning terhadap perilaku prososial anak usia dini. Penelitian ini menggunakan rancangan eksperimen single subject research dengan tiga anak TK Kelompok B sebagai subjek penelitian. Pengumpulan data menggunakan rating scale perilaku prososial, menunjukkan peningkatan perilaku prososial pada ketiga subjek. Hasil penelitian ini menunjukkan bahwa project based learning berpengaruh terhadap perilaku prososial anak usia dini.
\end{abstract}

Perilaku prososial merupakan bagian dari bidang perkembangan sosial emosional yang sangat penting untuk bersosialisasi. Perilaku prososial perlu distimulasi dan dikembangkan sejak dini karena pada masa ini otak dapat menyerap berbagai informasi secara maksimal. Bentuk-bentuk khas prososial diharapkan muncul pada perkembangan anak (Carlo et al., 2011). Perilaku prososial yang dikembangkan sejak dini dapat terbawa hingga dewasa. Anak ketika masa kecil telah memiliki perilaku prososial, jarang tumbuh menjadi antisosial ketika dewasa (Smith \& Hart, 2011). Pentingnya pengembangan perilaku prososial ini didukung oleh penelitian yang menyatakan bahwa permainan prososial berdampak positif dalam hal belajar saling membantu, peduli serta bekerjasama (Greitemeyer \& Osswald, 2010).

Fakta di lapangan menunjukkan bahwa proses pembelajaran untuk pengembangan perilaku prososial belum maksimal. Pengembangan perilaku prososial belum menyeluruh pada ranah kognitif, afektif, dan psikomotor. Anak kurang mendapat kesempatan berinteraksi dalam kelompok untuk belajar berperilaku prososial secara alami. Berdasarkan hasil pengamatan yang dilakukan di TK Dharma Wanita 2 Karangbesuki Kota Malang, diketahui bahwa perilaku prososial anak tergolong rendah, belum sesuai standar yang seharusnya. Perlu adanya upaya mengembangkan perilaku prososial anak secara terencana dan sistematis. Pengembangan perilaku prososial dapat dilakukan dengan berbagai pendekatan, model dan metode pembelajaran. Anak perlu berinteraksi dalam kelompok serta bekerjasama dalam kelompok kecil dalam rangka optimalisasi pengembangan perilaku prososialnya. Hal ini sesuai pendapat (Kärtner et al., 2010) bahwa sosialisasi berpengaruh secara signifikan terhadap perilaku prososial anak usia dini. Unsur saling mengenal dan kedekatan antara anak yang satu dengan yang lainnya menjadi salah satu pemicu munculnya perilaku prososial. Hal ini dikuatkan dengan pendapat (Poorthuis, 2016) bahwa perilaku prososial pada anak usia dini cenderung akan ditampilkan kepada anak yang dekat maupun yang telah dikenal.

Salah satu bentuk intervensi pendidikan yang dapat diterapkan dalam rangka pengembangan perilaku prososial anak usia dini adalah project based learning. Anak tidak hanya bekerja dalam kelompok, tetapi juga diberi kesempatan untuk bekerjasama menghasilkan suatu produk. Produk yang dihasilkan dalam project based learning ini bukan karya individu, tetapi hasil kerjasama kelompok. Oleh karena itu, anak usia dini dapat saling memberi dan menerima gagasan antar anggota kelompok. Interaksi yang terjadi pada proses menghasilkan suatu produk tersebut diharapkan mampu mendorong anak untuk menunjukkan perilaku prososial, seperti berbagi, menolong, dan bekerjasama. Hal ini dikuatkan dengan pendapat bahwa pembelajaran proyek berbasis budaya lokal dapat merangsang kecerdasan majemuk anak usia dini, termasuk yang terkait dengan perilaku prososial 
(Widiastuti, 2012). Penelitian Mayangsari, Sari, \& Munaila (2017) juga menunjukkan bahwa perilaku prososial pada anak usia dini dapat ditingkatkan dengan penerapan kegiatan aktif berkelompok yaitu outbond. Penelitian Jumrodah \& Hujjatusnaini (2013) juga menunjukkan adanya pengaruh project based learning terhadap peningkatan kemampuan bekerjasama, yang merupakan salah satu aspek perilaku prososial.

Perilaku prososial merupakan tindakan positif yang muncul dalam proses interaksi sosial. Perilaku prososial mengacu pada tindakan suka rela dengan maksud menolong atau menguntungkan individu atau kelompok lain (Eisenberg \& Mussen, 1989) berdampak positif bagi individu lain (Watson \& Axford, 2018) baik secara fisik maupun psikis (Muryanto, Kadafi, Trisnani, Yuniar, 2014). Jadi, tindakan ini ini dilakukan secara sukarela (voluntary) dan menguntungkan (benefit) orang lain tanpa motif reward eksternal. Sementara itu, menurut Standar Nasional Pendidikan Indonesia, perilaku prososial dalam kurikulum PAUD menjadi bagian dari standar isi, yaitu pada aspek perkembangan sosial emosional (Peraturan Menteri Pendidikan dan Kebudayaan Republik Indonesia Nomor 137 Tahun 2014 tentang Standar Nasional Pendidikan Anak Usia Dini, 2014). Perilaku prososial pada PAUD adalah capaian perkembangan pada aspek sosial emosional yang dapat menimbulkan keuntungan bagi individu secara ikhlas tanpa mengharapkan balasan.

Aspek-aspek perilaku prososial, biasanya juga disebut sebagai bentuk-bentuk perilaku prososial. Bentuk-bentuk khas prososial menurut Carlo et al. (2011) terdiri atas perilaku berbagi, menyumbang, menghibur, menjadi sukarelawan dan membantu orang lain. Menurut pendapat Mussen, Conger, \& Kagan (1989) aspek perilaku prososial mencakup berbagi, bekerjasama, menyumbang, menolong, dan jujur. Perkembangan perilaku prososial dipengaruhi oleh berbagai faktor. Faktorfaktor yang memengaruhi perilaku prososial menurut (Ulutas \& Aksoy, 2009) terdiri atas faktor individu yang meliputi gender gender, temperamen dan usia, dan faktor lingkungan seperti karakter lingkungan, budaya, gaya pengasuhan orangtua, saudara dan teman sebaya, serta program sekolah dan guru.

Menurut pendapat Staub (1978) faktor-faktor yang menyebabkan munculnya perilaku prososial adalah (1) the situation, (2) temporary states of potential helpers, (3) relationship to potential recipients of help, (4) personality characteristics, dan (5) psychological processes. Faktor yang memengaruhi perilaku prososial menurut Eisenberg \& Mussen (1989) ada enam, yaitu (1) biologis keanggotaan atau budaya kelompok; (2) pengalaman sosialisasi; (3) proses kognitif; (4) responsif emosional; (5) variabel kepribadian dan pribadi seperti sosialisasi dan gender; (6) kondisi dan keadaan situasional. Dari beberapa pendapat ahli tentang faktor perilaku prososial tersebut, dapat ditarik kesimpulan bahwa perilaku prososial dapat dipengaruhi oleh lingkungan, seperti program pembelajaran guru di sekolah yang dapat memberikan pengalaman sosialisasi serta stimulus dan kondisi yang tepat.

Project based learning atau biasa disebut pembelajaran berbasis proyek adalah pembelajaran yang inovatif dan berpusat pada anak. Model ini merupakan intergrated learning yang mencakup berbagai bidang pengembangan pada kegiatannya, menekankan pada belajar kontekstual sebagai upaya pemecahan masalah. Project based learning adalah model pembelajaran yang menggunakan proyek atau kegiatan sebagai inti pembelajaran (Kemendikbud, 2014) dilakukan perseorangan maupun kelompok, dalam jangka waktu tertentu untuk menghasilkan produk yang ditampilkan atau dipresentasikan (Sumarmi, 2012). Project based learning dalam penelitian ini dilaksanakan secara berkelompok untuk memberi kesempatan anak berinteraksi, bekerjasama, dan belajar prososial secara alamiah.

Project based learning merupakan salah satu model yang dapat diterapkan dalam kurikulum 2013. Proyek secara berkelompok lebih tepat diterapkan pada anak usia dini, agar anak belajar dari teman sebaya, saling berbagi, membantu dan bekerjasama. Intervensi pendidikan berupa project based learning dapat menjadi alternatif pengembangan perilaku prososial. Tujuan penelitian ini adalah mengetahui pengaruh project based learning terhadap perilaku prososial anak usia dini.

\section{METODE}

Rancangan penelitian ini menggunakan single subject research. Pendekatan eksperimen Single Subject Design meneliti subjek pada kondisi asli tanpa treatment, dan dengan pemberian treatment, serta akibatnya terhadap variabel yang diukur dalam kondisi tersebut. Desain rancangan subjek tunggal yang digunakan dalam penelitian ini adalah A-B-A, untuk meneliti perubahan perilaku prososial subjek.

Populasi pada penelitian ini adalah semua anak Kelompok B TK Dharma Wanita 2 Karangbesuki Kota Malang tahun ajaran 2019/2020 yang berjumlah 26 anak. Dari populasi tersebut, terdapat tujuh anak yang memiliki perilaku prososial rendah menjadi populasi target penelitian. Tiga anak yang menjadi subjek penelitian dipilih dari populasi target menggunakan metode random sampling.

Penelitian ini menggunakan dua jenis instrument, yaitu (1) Rencana Pelaksanaan Pembelajaran (RPP) project based learning dan (2) instrumen pengumpulan data berupa rating scale perilaku prososial. Rating scale perilaku prososial mengacu pada model skala Likert. Data perilaku prososial diamati berdasarkan kisi-kisi perkembangan perilaku prososial. Peneliti mengambil tiga aspek perilaku prososial, yaitu berbagi, menolong, dan bekerjasama. Pada instrumen ini, terdapat empat pilihan jawaban untuk mendata perilaku prososial, yaitu Belum Berkembang (BB), Mulai Berkembang (MB), Berkembang Sesuai Harapan (BSH) dan Berkembang Sangat Baik (BSB). 


\section{HASIL}

Data hasil penelitian, subjek F pada baseline (A), level dan central tendency menunjukkan perilaku berbagi dengan teman (sharing), bersikap kooperatif dengan teman (cooperating), dan menolong teman (helping) rendah, yaitu pada kisaran skor 3-5. Peneliti memutuskan menerapkan intervensi berupa model project based learning pada fase intervensi (B). Setelah dilakukan intervensi (B), skor perilaku prososial subjek F meningkat dari kisaran 3-10. Level dan trend perilaku prososial subjek F mengalami peningkatan cukup tajam menjadi kategori sedang (7-9) dan tinggi (10—12). Selanjutnya, untuk mengetahui apakah peningkatan perilaku prososial merupakan pengaruh intervensi penerapan project based learning atau terdapat faktor lain yang memengaruhi, selanjutnya peneliti menarik intervensi dan mengembalikan subjek $\mathrm{F}$ pada kondisi baseline (A').

Ketika intervensi (B) ditarik kembali, terjadi sedikit penurunan skor perilaku berbagi dengan orang lain (sharing) subjek F, dari 10 menjadi 8, artinya terdapat penurunan level dari kategori tinggi (10-12) menjadi kategori sedang (7-9). Sedangkan skor bersikap kooperatif dengan teman (cooperating) masih tetap di kisaran $8-7$ (kategori sedang). Skor perilaku menolong teman (helping) mengalami penurunan skor dari 10 (kategori tinggi) menjadi 7 (kategori sedang). Meskipun mengalami penurunan, namun seluruh skor perilaku prososial pada baseline (A') lebih tinggi yaitu pada kisaran 7 -8 (level sedang), dibandingkan skor pada saat sebelum intervensi (A), yaitu level rendah kisaran 3-5.

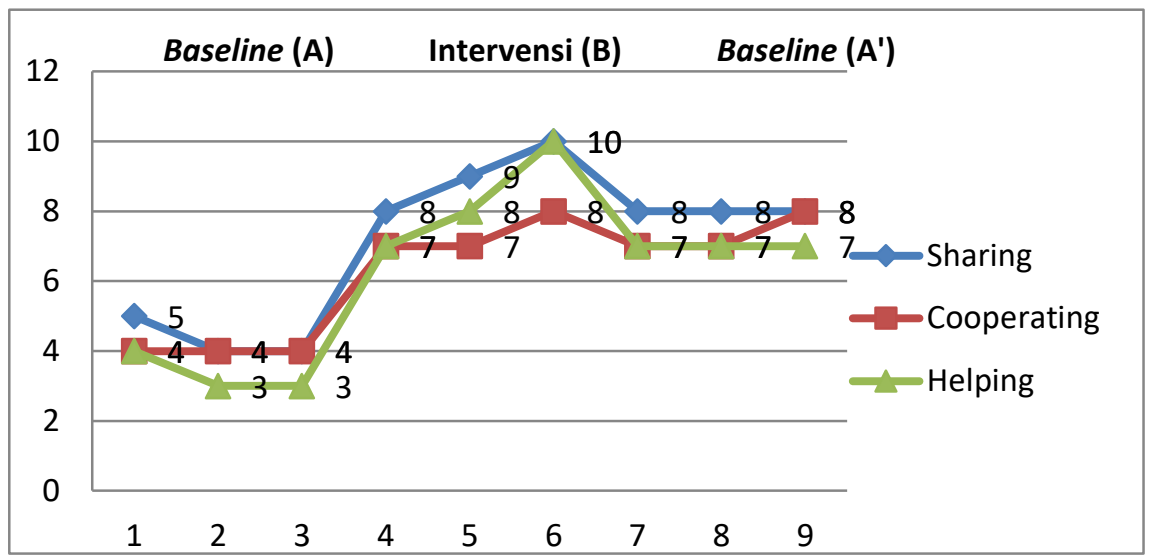

Gambar 1. Data Hasil Rating Scale Perilaku Prososial Subjek F pada Baseline (A')

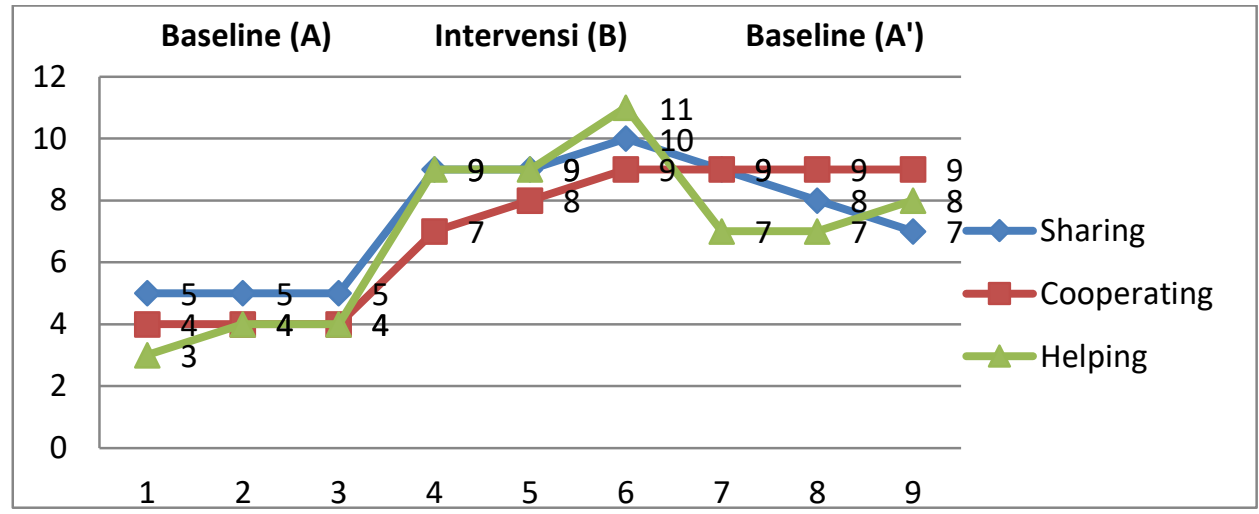

Gambar 2. Data Hasil Rating Scale Perilaku Prososial Subjek N pada Baseline (A')

Data hasil penelitian dan analisis data pada subjek $\mathrm{N}$ pada baseline (A) menggambarkan level dan central tendency perilaku prososial berbagi dengan teman (sharing), bersikap kooperatif dengan teman (cooperating), dan menolong teman (helping) sebelum dilakukan intervensi masih rendah, yaitu masing-masing pada kisaran 3, 4, dan 5 poin. Peneliti memutuskan untuk menerapkan intervensi pendidikan berupa model project based learning pada fase intervensi (B). Setelah subjek $\mathrm{N}$ diberi intervensi (B) terdapat peningkatan skor perilaku prososial. Peningkatan level dan trend, terutama pada perilaku menolong teman yaitu dari skor 4 menjadi 11. Perilaku prososial meningkat dari kisaran skor 3-11. Level perilaku prososial meningkat cukup tajam menjadi kategori sedang (7-9) dan meningkat tajam menjadi kategori tinggi (10-12). Selanjutnya, untuk mengetahui apakah peningkatan perilaku prososial AUD merupakan pengaruh intervensi atau faktor lain maka peneliti menarik intervensi. 
Skor perilaku prososial subjek $\mathrm{N}$ mengalami sedikit penurunan level ketika intervensi (B) ditarik kembali. Skor perilaku prososial subjek $\mathrm{N}$ pada saat intervensi (B) yang berada pada kisaran 7-11, menurun pada kisaran 7-9. Level perilaku prososial kategori sedang (7-9) dan tinggi (10-12) pada saat intervensi, menurun menjadi kategori sedang (7-9) . Level perilaku prososial subjek N pada saat baseline (A') yaitu 7-9 poin (kategori sedang), lebih tinggi daripada skor pada saat baseline (A) sebelum intervensi, yaitu kisaran 3-5 (kategori rendah).

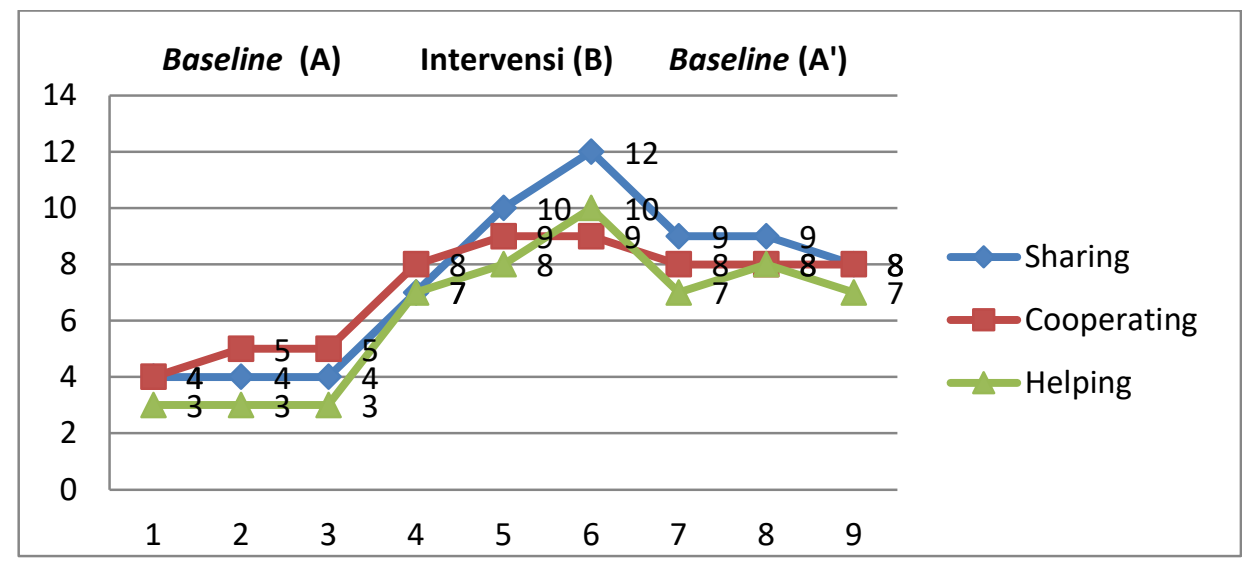

Gambar 3. Data Hasil Rating Scale Perilaku Prososial Subjek Z pada Baseline (A')

Data hasil penelitian subjek $\mathrm{Z}$ pada baseline (A) menunjukkan level dan central tendency perilaku prososial sharing, cooperating, helping masih rendah, yaitu pada kisaran 3-5. Peneliti memutuskan untuk menerapkan project based learning pada fase intervensi (B). Perilaku prososial subjek Z meningkat ketika dilakukan intervensi, yaitu dari kisaran 3-12. Level dan trend perilaku prososial subjek Z mengalami peningkatan tajam dari level rendah (4-6) ke level tinggi (10-12). Untuk mengetahui apakah peningkatan perilaku prososial merupakan pengaruh penerapan project based learning atau terdapat faktor lain, peneliti menarik intervensi dan mengembalikan subjek $\mathrm{Z}$ pada kondisi baseline (A').

Setelah intervensi (B) ditarik kembali, terjadi penurunan skor perilaku prososial subjek Z dari kisaran 9-12 (kategori tinggi), menjadi kisaran 7-9 (kategori sedang). Meskipun mengalami penurunan skor, level perilaku prososial subjek Z ketika baseline (A') lebih tinggi daripada skor pada baseline (A) sebelum intervensi, yaitu kisaran 3-5 (kategori rendah).

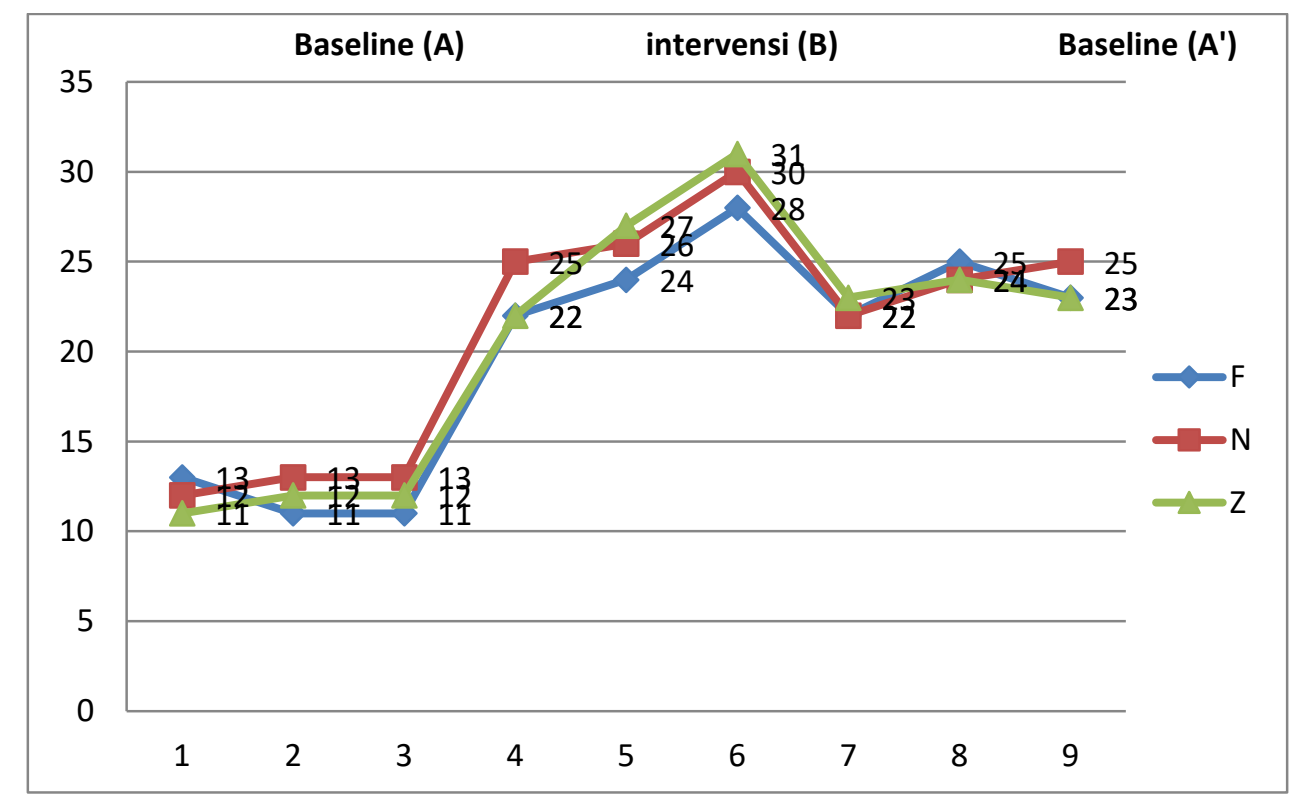

Gambar 4. Data Hasil Rating Scale Perilaku Prososial Subjek F, N, dan Z 
Data hasil penelitian menunjukkan subjek F, N, dan Z mengalami peningkatan skor perilaku prososial saat dan setelah dilakukan intervensi pendidikan berupa project based learning. Peningkatan skor ketiga subjek keseluruhan aspek perilaku prososial yang diamati pada penelitian ini, yaitu perilaku berbagi dengan teman (sharing ), bersikap kooperatif dengan teman (cooperating), dan menolong teman (helping). Pada fase baseline (A) skor perilaku prososial subjek F, subjek N dan subjek Z berada pada kategori rendah (9-17) yaitu pada kisaran 11-13 poin. Ketika intervensi diterapkan, skor prososial ketiga subjek meningkat menjadi kategori sedang (18-26) dan kategori tinggi (27-36), yaitu pada kisaran 22-31 poin. Setelah intervensi ditarik kembali pada baseline (A'), skor perilaku prososial ketiga subjek mengalami sedikit penurunan ke kategori sedang (1826) yaitu pada kisaran $22-25$ poin. Meskipun mengalami penurunan skor, tetapi level perilaku prososial ketiga subjek pada saat baseline (A') yaitu 22-25 poin (kategori sedang), lebih tinggi daripada skor pada saat baseline (A) sebelum intervensi, yaitu kisaran 9-17 poin (kategori rendah).

\section{PEMBAHASAN}

Berdasarkan hasil analisis data yang dipaparkan, dapat diketahui bahwa perilaku prososial ketiga subjek mengalami peningkatan setelah dilakukan intervensi pendidikan. Pada fase baseline (A), perilaku prososial anak berada pada level rendah, pada kisaran skor 3-5. Ketika diterapkan project based learning, perilaku prososial anak meningkat hingga kisaran skor 7 - 12 . Perilaku prososial anak meningkat pada level sedang (7-9) dan tinggi (10-12). Level dan central tendency meningkat setelah dilakukan intervensi. Hal ini dapat dilihat pada paparan data visual yang menunjukkan adanya perubahan skor dan level perilaku prososial anak secara signifikan, sehingga dapat diintrepretasikan bahwa project based learning berpengaruh terhadap perilaku prososial anak usia dini.

Hasil penelitian ini sesuai oleh penelitian yang menyatakan bahwa permainan prososial berdampak positif terhadap diri seseorang dalam hal belajar saling membantu, peduli serta bekerjasama (Greitemeyer \& Osswald, 2010). Hasil penelitian ini menyebutkan adanya pengaruh yang signifikan video games prososial terhadap perilaku prososial. Hasil ini juga sejalan dengan penelitian tentang peningkatan perilaku prososial anak usia dini yang menunjukkan bahwa perilaku prososial pada anak usia dini dapat ditingkatkan dengan penerapan kegiatan aktif berkelompok yaitu outbond (Mayangsari, Sari, \& Munaila, 2017). Kegiatan outbond fun estafet pada anak memungkinkan adanya interaksi sosial yang membuat anak aktirf dalam pembelajaran. Perilaku prososial anak meningkat dari $31 \%$ menjadi $86,20 \%$ dengan penerapan kegiatan outbond fun estafet pada anak kelompok A. Hasil ini mendukung penelitian lain yang dilaksanakan oleh (Jumrodah \& Hujjatusnaini, 2013) tentang pengaruh pembelajaran berbasis proyek (project based learning) terhadap hasil belajar dan kemampuan bekerjasama. Tujuan penelitian ini adalah untuk mengetahui pengaruh pembelajaran berbasis proyek terhadap hasil belajar dan kemampuan bekerjasama. Hasil penelitian menunjukkan adanya peningkatan sebesar 65,61\% kemampuan bekerjasama setelah penerapan project based learning.

Penerapan intervensi pendidikan yaitu project based learning dengan asumsi bahwa perilaku prososial juga dipengaruhi oleh faktor situasi. Salah satu unsur dari faktor situasi adalah sifat stimulus untuk perilaku prososial, serta sifat dan kondisi di sekitar stimulus itu terjadi. Stimulus yang tepat dan diberikan pada situasi tepat, dapat memicu munculnya perilaku prososial anak (Staub, 1978). Sejalan dengan pendapat tersebut (Eisenberg \& Mussen, 1989) berpendapat bahwa faktor lingkungan, termasuk pengalaman dalam bersosialisasi turut menyumbangkan faktor perilaku prososial. Pengembangan perilaku prososial dapat dilakukan dengan berbagai pendekatan, model dan metode pembelajaran, seperti project based learning. Perilaku prososial dapat diperoleh serta dapat dimodifikasi melalui penelitian praktis berdasarkan pengetahuan ilmiah secara sistematis.

Pembelajaran dengan project based learning direncanakan secara khusus dengan mengangkat tema-tema prososial, memberikan kesempatan bagi anak untuk berperilaku prososial dalam kelompok, tanpa diperintah oleh guru. Perilaku prososial yang direncanakan untuk dapat dilakukan oleh anak, terjadi karena proses interaksi dan kerjasama dalam rangka meraih tujuan bersama, yaitu hasil karya proyek. Saat baseline (A'), subjek F, subjek N dan subjek Z mengalami sedikit penurunan skor dan level, menjadi kategori sedang. Hasil penelitian ini masih sesuai dengan teori perkembangan sosial AUD. Pada anak usia 5-6 tahun, perkembangan sosial anak sudah cukup baik. Penelitian ini sesuai dengan pendapat bahwa aspek-aspek penyesuaian sosial terdiri atas penampilan nyata (tentang bagaimana individu dapat memenuhi harapan kelompoknya), penyesuaian diri terhadap kelompok (bagaimana individu beradaptasi dengan kelompok), sikap sosial (sikap baik yang ditunjukkan individu ketika mampu beradaptasi dengan kelompok), dan kepuasan pribadi (adanya kesadaran diri) (Hurlock, 1980). Pada usia ini, AUD cenderung sudah dapat menghindari tampil menonjol, sebagai bagian dari usaha penyesuaian diri dengan kelompoknya. Perilaku yang terlalu menonjol dapat dianggap tidak menguntungkan bagi mereka, karena akan sulit diterima oleh kelompoknya.

Langkah-langkah project based learning yang memberikan kesempatan bagi anak untuk aktif dalam kegiatan kelompok, saling bekerjasama, saling berbagi, saling menolong, saling memberikan pendapat, saling memberi semangat dalam rangka menghasilkan produk yang diinginkan. Anak menjadi pusat pembelajaran, berperan aktif dalam upaya peningkatan perilaku prososial dalam proses interaksi. Pengalaman sosialisasi dan berperilaku prososial dalam kelompok ini menjadi modal dasar untuk berperilaku prososial pada masa selanjutnya. 
Project based learning memungkinkan interaksi yang terjadi ketika proses menghasilkan suatu produk. Pada proses berkarya tersebut diharapkan mampu mendorong anak untuk menunjukkan perilaku prososial seperti berbagi, menolong, dan bekerjasama dalam kelompok. Produk yang dihasilkan dalam project based learning bukan karya individu, melainkan hasil kerjasama individu dalam kelompok. Oleh karena itu, anak dapat saling memberi, menerima gagasan dan pemikiran antar anggota kelompok. Hal ini sesuai dengan hasil penelitian yang menunjukkan sosialisasi berpengaruh signifikan terhadap perilaku prososial anak usia dini (Kärtner et al., 2010).

Intervensi pendidikan berupa project based learning memberi kesempatan anak untuk belajar berperilaku prososial. Setelah pemberian intervensi, ketiga subjek menunjukkan peningkatan dalam perilaku prososial. Anak lebih sering bermain bersama teman, membantu teman dan guru di sekolah, membantu orangtua di rumah, berbagi makanan, minuman atau mainan dengan teman. Perubahan perilaku ini juga dirasakan oleh guru di sekolah dan orangtua. Ketika kegiatan bermain, anak tidak lagi terlibat saling berebut mainan. Mereka dapat bermain bergantian dengan teman, bahkan meminjamkan mainannya pada teman, juga mengambilkan mainan untuk temannya. Perubahan ke arah positif dalam perilaku prososial ini membuat ketiga subjek lebih diterima dalam pertemanan. Perilaku prososial yang dikembangkan sejak dini dapat menjadi perilaku yang terbawa hingga dewasa. Anak yang ketika masa kecil telah memiliki perilaku prososial jarang menjadi antisosial ketika dewasa (Smith \& Hart, 2011).

\section{SIMPULAN}

Berdasarkan hasil analisis data dan pembahasan, maka dapat disimpulkan bahwa intervensi pendidikan yaitu penerapan model project based learning berpengaruh dalam meningkatkan perilaku prososial anak usia dini. Hasil yang didapatkan oleh masing-masing subjek penelitian, yaitu subjek F, N, dan Z mengalami kenaikan. Hasil tersebut membuktikan bahwa model project based learning berpengaruh terhadap perilaku prososial anak usia dini.

Pendidik PAUD dapat mengimplementasikan project based learning dalam pembelajaran. Kepala Lembaga PAUD untuk peningkatan mutu pendidikan, serta mendorong inovasi-inovasi pembelajaran dalam rangka mencapai tujuan pembelajaran, terutama pada perilaku prososial anak usia dini. Penelitian ini diharakan dapat menjadi bahan rujukan bagi penelitian sejenis, serta penerapan pada bidang pengembangan anak usia dini lainnya, seperti kognitif, fisik motorik, bahasa, dan seni.

\section{DAFTAR RUJUKAN}

Anderson, D.W., Vault, V. D. \& Dickson, C. E. (1999). Problems and Prospects for the Decades Ahead: Competency Based Teacher Education. Alfiyah, S., \& Martani, W. (2016). Validasi Modul Bermain Peran “Aku Sayang Kawan” untuk Meningkatkan Pengetahuan Perilaku Prososial pada AUD. Gadjah Mada Journal of Professional Psychology (GamaJPP), 1(2), 120-137.

Asih, G. Y., \& Pratiwi, M. M. S. (2010). Perilaku Prososial Ditinjau Dari Empati dan Kematangan Emosi. Jurnal Psikologi Universitas Muria Kudus, 1(1), 33-42.

Cakiroglu, O. (2012). Single Subject Research: Applications to Special Education. British Journal of Special Education, 39(1), 21-29. http://doi.org/10.1111/j.1467-8578.2012.00530.x diakses 22 Agustus 2019)

Carlo, G., Mestre, M. V., Samper, P., Tur, A., \& Armenta, B. E. (2011). The Longitudinal Relations among Dimensions of Parenting Styles, Sympathy, Prosocial Moral Reasoning, and Prosocial Behaviors. International Journal of Behavioral Development, 35(2), 116-124.

Daryanto. (2014). Pendekatan Pembelajaran Saintifik Kurikulum 2013. Yogyakarta: Gaya Media.

Eisenberg, N., \& Mussen, P. H. (1989). The Roots of Prosocial Behavior in Children. United Kingdom: Cambridge University Press.

Eysenck, M. W., \& Eysenck, M. W. (2018). Prosocial behaviour. Simply Psychology, (February), 210-225. http://doi.org/10.4324/9781315517933-17

Gregory, R. J. (2013). Tes Psikologi Sejarah, Prinsip dan Aplikasi. Jakarta: Erlangga.

Greitemeyer, T., \& Osswald, S. (2010). Effects of Prosocial Video Games on Prosocial Behavior. Journal of Personality and Social Psychology, 98(2), 211-221. http://doi.org/10.1037/a0016997

Hiscocks, P. D. (2011). Project-Based-Learning: Outcomes, Descriptors and Design. Proceedings of the Canadian Engineering Education Association (CEEA).

Hurlock, E. B. (1980). Psikologi Perkembangan. Jakarta: Erlangga.

Hurlock, E. (1978). Perkembangan Anak Jilid 1. Jakarta: Gramedia Pustaka Utama.

Jumrodah., \& Hujjatusnaini, N. (2013). Pengaruh Pembelajaran Berbasis Proyek (Project Based Lerning) terhadap Hasil Belajar dan Kemampuan Bekerjasama Mahasiswa pada Matakuliah Teknik Pengelolaan Laboratorium Program Studi Tadris Biologi. Jurnal Edu Sains, 1(1), 39-46.

Kärtner, J., Keller, H., \& Chaudhary, N. (2010). Cognitive and Social Influences on Early Prosocial Behavior in Two Sociocultural Contexts. Developmental Psychology, 46(4), 905-914. 
Kemendikbud. (2013). Model Pengembangan Berbasis Proyek (Project Based Learning). Jakarta: Kementrian Pendidikan dan Kebudayaan.

Kemendikbud. (2014). Materi Pelatihan Guru Implementasi Kurikulum 13. Kementrian Pendidikan dan Kebudayaan.

Matondang, E. S. (2017). Perilaku Prososial (Prosocial Behavior) AUD Dan Pengelolaan Kelas Melalui Pengelompokan Usia Rangkap (Multiage Grouping). EduHumaniora | Jurnal Pendidikan Dasar Kampus Cibiru, 8(1), 34.

Mayangsari, D., Sari, E. D. N., \& Munaila, N. (2017). Peningkatan Perilaku Prososial pada Anak Usia 4-5 Tahun Melalui Kegiatan Outbond Fun Estafet di Tk PGRI Langkap Burneh Bangkalan. Jurnal PG-PAUD Trunojoyo: Jurnal Pendidikan dan Pembelajaran AUD, 4(2), 115. http://doi.org/10.21107/jpgpaud.v4i2.3574.

Kau, M. A. (2010). Empati dan Perilaku Prososial Pada Anak. Jurnal Inovasi, 7(3), 1-5.

Mussen, P. H., Conger, J. J \& Kagan, J. (1989). Child Development and Personality (Fifth Edition). Harper and Row Publisher. Muryanto, H., Kadafi, A., Trisnani, R. P. \& Yuniar, V. (2014). Terapi “Ber-Bi” untuk Meningkatkan Perilaku Prososial pada Siswa TK Desa Sewulan Madiun Tahun 2014. Jurnal LPPM, 3(1), 39-44.

Peraturan Menteri Pendidikan dan Kebudayaan Republik Indonesia Nomor 137 Tahun 2014 tentang Standar Nasional Pendidikan AUD. (2014). Jakarta: Kemendikbud.

Peraturan Menteri Pendidikan dan Kebudayaan Republik Indonesia Nomor 146 Tahun 2014 tentang Kurikulum 13 Pendidikan AUD. (2014). Jakarta: Kemendikbud.

Poorthuis, A.M.G., Thomaes, S., Denissen, J. J. A., Van Aken, M.A.G., \& De Castro, B. (2012). Prosocial Tendencies Predict Friendship Quality, but not for Popular Children. Journal of Experimental Child Psycology, 112(4), 378-388.

Purnomo, E.A., \& Mawarsari, V. (2014). Peningkatan Kemampuan Pemecahan Masalah Melalui Pembelajaran Ideal Problem Solving Berbasis Project Based Learning. JKPM, 1(1), 24-31.

Smith, P. K., \& Hart, C. H. (2011). Childhood Social Development. Second Edition (keenam). West Sussex: Blackwell Publishing, Ltd.

Sugiyono. (2010). Statistika untuk Penelitian. Bandung: Alfabeta.

Sumarmi. (2012). Model-model Pembelajaran. Malang: Aditya Media.

Sunanto, J., Takeuchi, K., \& Nakata, H. (2005). Pengantar Penelitian Dengan Subjek Tunggal. CRICED University of Tsukuba, 1-150. http://doi.org/10.5607/en.2016.25.1.33.

Thomas, J.W., \& D, P. (2000). A Review of Research on Project Based Learning. California: The Autodesk Foundation.

Undang-undang Republik Indonesia Nomor 20 Tahun 2003 tentang Sistem Pendidikan Nasional. (2004). Jakarta: Kemdikbud.

Waluyo, D.A., \& Listyowati, A. (2017). Komendium PAUD: Memahami PAUD Secara Singkat. Depok: Prenadamedia Group.

Watson, L., \& Axford, B. (2018). Characteristics and Delivery of Early Childhood Education Degrees in Australia. Canberra: Live Long Learning.

Widiastuti, S. (2012). Pembelajaran Proyek Berbasis Budaya Lokal untuk Menstimulasi Kecerdasan Majemuk AUD. Jurnal Pendidikan Anak, 1(1), 59-71. DOI: https://doi.org/10.21831/jpa.v1i1.2907 